\title{
SELF - EFFICACY MAHASISWA DALAM BELAJAR \\ PADA MASA PANDEMI COVID-19 \\ DI STIKES WILLIAM BOOTH
}

\author{
Aristina Halawa* \\ *Stikes William Booth, Jl.Cimanuk no.20 Surabaya. \\ Email : halawaaristina@yahoo.co.id
}

\begin{abstract}
ABSTRAK
Pandemi Covid-19 memberi dampak bukan hanya pada bidang Kesehatan tetapi juga pada bidang pendidikan dimana proses pembelajaran berubah menjadi pembelajaran daring. Hal ini mempengaruhi Self-Efficacy mahasiswa dalam belajar. Penelitian ini bertujuan untuk untuk mengidentifikasi Self-Efficacy mahasiswa dalam belajar pada masa pandemic Covid-19. Penelitian ini menggunakan desain deskriptif, dengan jumlah populasi 103 responden, dan jumlah sampel 103 responden mahasiwa yang mengisi kuisioner. Tehnik sampling yang digunakan yaitu Total sampling. Instrumen penelitian menggunakan kuesioner dalam pengambilan data. Analisa data menggunakan distribusi frekuensi. Hasil dari penelitian ini menunjukan bahawa sebagian besar mahasiswa memiliki Self-efficacy yang tinggi dalam belajar. Dengan demikian diharapkan institusi tetap meningkatkan proses pembelajaran yang kreatif dan interaktif agar dapat meningkatkan Self-Efficacy mahasiswa dalam belajar.
\end{abstract}

Kata Kunci : self-efficacy, belajar, mahasiswa,

\section{ABSTRACT}

The Covid-19 pandemic has an impact not only on the health sector but also on the education sector where the learning process turns into online learning. This affects students' Self-Efficacy in learning. This study aims to identify student self-efficacy in learning during the Covid-19 pandemic. This study used a descriptive design, with a population of 103 respondents, and a sample size of 103 student respondents who filled out a questionnaire. The sampling technique used is total sampling. The research instrument used a questionnaire to collect data. Data analysis using frequency distribution. The results of this study indicate that most students have high self-efficacy in learning. Thus, it is hoped that the institution will continue to improve the creative and interactive learning process in order to increase students' Self-Efficacy in learning.

Keywords: self-efficacy, Learning, Student 


\section{PENDAHULUAN}

Wabah Covid-19 telah ditetapkan oleh WHO pada tanggal 30 Januari 2020 sebagai darurat kesehatan masyarakat dan hal ini menjadi perhatian internasional karena memiliki resiko tinggi dan dampak yang besar khususnya pada negara negara yang system pelayanan kesehatannya masih rentan. (Firman, 2020). Di Indonesia sendiri mulai muncul wabah ini sejak bulan Maret 2020 dan hal ini menyebabkan banyak kebijakan kebijakan yang dikeluarkan oleh pemerintah untuk mencegah terjadinya penularan virus Covid-19 ini. (Khasanah, 2020). Selain sektor ekonomi, transportasi dan pertanian, Pandemi Covid-19 juga membawa pengaruh yang sangat besar bagi dunia pendidikan. Institusi-institusi pendidikan diharapkan untuk tidak melaksanakan kegiatan seperti biasanya yaitu pembelajaran tatap muka, tetapi pembelajaran dilakukan secara daring atau pembelajran jarak jauh. hal ini diharapkan untuk mengurangi penyebaran Covid-19. (Firman 2020)

Pembelajaran secara daring dan bekerja dari rumah bagi para tenaga pendidik merupakan perubahan yang harus dilakukan oleh dosen untuk tetap mengajar mahasiswa. Pendidikan dengan jarak jauh memiliki tujuan agar mutu pendidikan meningkatkan dan relevansi pendidikan serta meningkatkan pemerataan akses dan perluasan pendidikan. Kesulitan muncul bukan hanya perkara keterampilan penggunaan teknologi, tetapi juga terkait dengan beban kerja yang besar mengingat ada banyak mata kuliah yang harus dihadapi dalam masa pandemi COVID-19 ini. Hal ini terjadi karena mahasiswa terbiasa dengan pembelajaran tatap muka secara reguler, sedangkan pembelajaran jarak jauh sebelumnya hanya dilakukan secara insidental (Niken, 2020). Pendidikan di Sekolah Tinggi Ilmu Kesehatan yang memiliki program studi Keperawatan dan Kebidanan juga terdampak akan hal ini.
Jika selama ini dosen mengajar di kelas dan di laboratorium serta mendampingi mahasiswa untuk belajar di klinik maka hal ini tidak dapat dilkukan lagi. Demikian juga mahasiswa yang selama ini kalau selama ini selain belajar di kelas juga belajar ketrampilan di laboratorium dan dilanjutkan di klinik. Hal tersebut tidak dapat dilakukan lagi. Pada awalnya mahasiswa menganggap bahwa hal ini hanya sementara namun pandemic tidak belum juga berakhir sehingga hal ini berpengaruh pada psikologis mahasiswa dimana hal ini membuat mereka berpikir apakah mereka mampu untuk mencapai cita-cita mereka menjadi bidan dan perawat dengan situasi yang seperti ini, Timbul pemikiran dalam diri mahasiswa akan sulit melewati proses pembelajaran jarak jauh ini karena Pendidikan Kesehatan banyak memerlukan kegiatan belajar di laboratorium dan klinik. Mahasiswa tidak memiliki keyakinan untuk berhasil dalam belajar dengan metode daring.

Menurut Yolandaru (2020) mahasiswa memiliki kesempatan untuk belajar mandiri dengan adanya pembelajaran jarak jauh ini. Mahasiswa dapt meningkatkan motivasi dan Self-efficacy nya agar hasil belajarnya dapat meningkat. Efikasi diri merupakan keyakinan individu terhadap kemampuannya untuk melakukan tindakan yang diberikan kepadanya (Schunk, 1991). Menurut Bandura (1994) Self-efficacy adalah penilaian diri, apakah dapat melakukan tindakan yang baik atau buruk, tepat atau salah, bisa atau tidak bisa mengerjakan sesuai dengan yang dipersyaratkan. Self-Efficacy berhubungan dengan keyakinan seseorang akan kemampuannya untuk memengaruhi kejadian yang berhubungnan dengan kehidupan mereka. (Bandura, 2010).

Apabila seseorang memilki self-efficacy tinggi, maka seseorang tersebut akan berusaha untuk meningkatkan kemampuannya agar dapat menyelesaikan masalah yang dihadapinya. Sedangkan 
apabila seseorang memiliki Self-efficacy yang rendah maka dia akan menghindari masalah yang dihadapinya sehingga hal ini akan menghambat perkembangan selanjutnya. Demikian juga dengan mahasiswa yang dalam masa pandemic ini memiliki Self-efficacy yang tinggi maka mahasiswa tersebut akan terus berupaya beradaptasi dengan perubahan yang ada dan berusaha untuk menyelesaikan tugas dan masalah yang dihadapinya sehingga hal in ikan semakin meningkatkan kemampuannya yang tentunya akan berimplikasi pada hasil belajarnya. Mahasiwa yang memiliki Self-efficacy yang rendah hanya akan pasif dan menunggu pandemic ini akan segera selesai dan tidak berusaha untuk meningkatkan kemampuannya untuk beradaptasi terhadap perubahan proses pembalajaran yang terjadi.

Berdasarkan hasil penelitian Yolandaru Septiana (2020) dalam penelitiannya Survey Efikasi diri mahasiswa Prodi Akuntansi adalah Baik dimana hasilnya menunjukkan bahwa mahasiswa mempunyai keyakinan dapat mempelajari semua materi kuliah dengan usaha keras walaupun materi sulit. Mahasiswa mempunyai sikap positif terhadap kuliah. Mahasiswa yakin dengan berjalannya waktu akan semakin mampu mempelajari materi kuliah. Mahasiswa yakin dapat terus belajar walaupun terganggu di dalam kelas dan dapat mencapai tujuan akademik yang diinginkan dengan berusaha keras. Mahasiswa yakin mampu mengembangkan cara-cara kreatif untuk mengatasi stres yang terjadi di kuliah dan tetap termotivasi untuk berpartisipasi aktif dalam kuliah. Dari hasil penelitian ini menunjukkan bahwa mahasiswa yang memiliki Selfefficacy yang baik atau tinggi akan mampu mengatasi masalah, tetap berpikir positif, mampu berpikir kreatif.

\section{METODE}

Desain penelitian yang digunakan dalam penelitian ini adalah deskripstif yatu metode penelitian yang bertujuan untuk menjelaskan, situasi atau fenomena atau memberi suatu nama dalam menemukan ide baru (Nursalam, 2003).

Penelitian ini bertujuan untuk mengetahui gambaran Self-Efficacy mahasiswa pada masa new normal. Populasi dalam penelitian ini adalah seluruh mahasiswa Stikes William Booth yang bersedia mengisi kuisioner lewat google form. Yaitu sebanyak 103 mahasiswa.

Sampel dalam penelitian ini adalah seluruh mahasiswa Stikes William Booth yang bersedia mengisi kuisioner yaitu sejumlah 103 mahasiswa sesuai dengan teknik sampling yang dipergunakan yaitu total sampling.

Pengambilan data dilakukan dengan menyebarkan kuisioner melalui google form tentang Self-efficacy mahasiswa pada masa New normal. Cara menilai tingkat self efficacy pada pecandu narkoba mengggunakan kuesioner terdiri dari 4 indikator berupa 10 pertayaan. Jika pecandu bisa melakukan sesuai dengan indikator penelitian bila sangat setuju $=4$, setuju $=3$, tidak setuju $=2$, dan sangat tidak setuju $=1$.

\section{HASIL DAN PEMBAHASAN}

\section{Responden Berdasarkan Tingkat}

Tabel 1 Tabel distribusi responden berdasarkan berdasarkan Tingkat di STIKes William Booth

\begin{tabular}{|c|c|c|c|}
\hline No. & Tingkat & $\begin{array}{c}\text { Jumlah } \\
\text { Responden }\end{array}$ & $\begin{array}{c}\text { Presentase } \\
(\%)\end{array}$ \\
\hline 1. & $\begin{array}{c}\text { Tingkat } \\
\text { I }\end{array}$ & 29 & $28,3 \%$ \\
\hline 2. & $\begin{array}{c}\text { Tingkat } \\
\text { II }\end{array}$ & 35 & $34 \%$ \\
\hline 3. & $\begin{array}{c}\text { Tingkat } \\
\text { III }\end{array}$ & 8 & $7,8 \%$ \\
\hline 4. & $\begin{array}{c}\text { Tingkat } \\
\text { IV }\end{array}$ & 8 & $7,8 \%$ \\
\hline 5. & $\begin{array}{c}\text { Tingkat } \\
\text { V }\end{array}$ & 23 & 22,3 \\
\hline \multicolumn{2}{|c|}{ Total } & 103 & $100 \%$ \\
\hline
\end{tabular}


Berdasarkan Tabel 1 dapat diketahui bahwa paling banyak berada di tingkat II sebanyak 35 responden (34\%)

\section{Responden Berdasarkan Usia}

Tabel 2 Tabel distribusi responden berdasarkan berdasarkan Usia di STIKes William Booth

\begin{tabular}{|c|c|c|c|}
\hline $\begin{array}{c}\text { No } \\
\cdot\end{array}$ & Usia & $\begin{array}{c}\text { Jumlah } \\
\text { Responde } \\
\mathrm{n}\end{array}$ & $\begin{array}{c}\text { Presentas } \\
\mathrm{e}(\%)\end{array}$ \\
\hline 1. & 18 Tahun & 7 & $6,8 \%$ \\
\hline 2. & 19 Tahun & 23 & $22,3 \%$ \\
\hline 3. & 20 Tahun & 26 & $25,2 \%$ \\
\hline 4. & 21 Tahun & 12 & $11,7 \%$ \\
\hline 5. & 22 Tahun & 14 & $13,6 \%$ \\
\hline 6. & $\begin{array}{c}23>\text { Tahu } \\
\mathrm{n}\end{array}$ & 21 & $20,4 \%$ \\
\hline \multicolumn{2}{|c|}{ Total } & 103 & $100 \%$ \\
\hline
\end{tabular}

Berdasarkan Tabel 2 dapat diketahui bahwa paling banyak responden berusia 20 tahun yaitu sebanyak 26 responden $(25,2 \%)$.

\section{Responden Berdasarkan Jenis Kelamin}

Tabel 3 Tabel distribusi responden berdasarkan berdasarkan Jenis Kelamin di STIKes William Booth

\begin{tabular}{|c|c|c|c|}
\hline $\begin{array}{c}\text { No } \\
\cdot\end{array}$ & $\begin{array}{c}\text { Jeniskelami } \\
\mathrm{n}\end{array}$ & $\begin{array}{c}\text { Jumlah } \\
\text { Responde } \\
\mathrm{n}\end{array}$ & $\begin{array}{c}\text { Presentas } \\
\mathrm{e}(\%)\end{array}$ \\
\hline 1. & Laki laki & 16 & $15,5 \%$ \\
\hline 2. & Perempuan & 87 & $84,5 \%$ \\
\hline 3. & & - & $0 \%$ \\
\hline \multicolumn{2}{|c|}{ Total } & 103 & $100 \%$ \\
\hline
\end{tabular}

Berdasarkan Tabel 3 dapat diketahui bahwa mayoritas responden berjenis kelamin yaitu sebanyak 87 responden $(84,5 \%)$

\section{Responden Berdasarkan Pendidikan Orang Tua}

Tabel 4 Tabel distribusi responden berdasarkan berdasarkan Tingkat pendididkan Orang tua di STIKes William Booth

\begin{tabular}{|c|c|c|c|}
\hline No & $\begin{array}{c}\text { Pendidikan } \\
\text { Orang tua }\end{array}$ & $\begin{array}{c}\text { Jumlah } \\
\text { Respond } \\
\text { en }\end{array}$ & $\begin{array}{c}\text { Presenta } \\
\text { se }(\%)\end{array}$ \\
\hline 1. & SD & 19 & $18,4 \%$ \\
\hline 2. & SMP & 13 & $24,6 \%$ \\
\hline 3. & SMA & 47 & $45,6 \%$ \\
\hline 4. & $\begin{array}{c}\text { Diploma/Sarj } \\
\text { ana }\end{array}$ & 24 & $23,3 \%$ \\
\hline \multicolumn{2}{|r|}{ Total } & 103 & $100 \%$ \\
\hline
\end{tabular}

Berdasarkan Tabel 4 dapat diketahui bahwa Sebagain besar responden orangtuanya memiliki tingkat pendidikan SMA yaitu sebanyak 47 responden $(45,6 \%)$

\section{Responden Berdasarkan Pekerjaan Orang tua}

Tabel 5 Tabel distribusi responden berdasarkan berdasarkan Pekerjaan orang tua di STIKes William Booth

\begin{tabular}{|c|c|c|c|}
\hline No & $\begin{array}{c}\text { Pekerjaan } \\
\text { Orang Tua }\end{array}$ & $\begin{array}{c}\text { Jumlah } \\
\text { Responde } \\
\text { n }\end{array}$ & $\begin{array}{c}\text { Presentas } \\
\text { e }(\%)\end{array}$ \\
\hline 1. & PNS & 12 & $11,7 \%$ \\
\hline 2. & $\begin{array}{l}\text { Pegawai } \\
\text { Swasta }\end{array}$ & 30 & $29,1 \%$ \\
\hline 3. & $\begin{array}{c}\text { Wiraswast } \\
\mathrm{a}\end{array}$ & 49 & $47,6 \%$ \\
\hline 4. & $\begin{array}{c}\text { Tidak } \\
\text { Bekerja }\end{array}$ & 12 & $11,7 \%$ \\
\hline \multicolumn{2}{|r|}{ Total } & 103 & $100 \%$ \\
\hline
\end{tabular}

Berdasarkan Tabel 5 dapat diketahui bahwa paling banyak pekerjaan orang tua yaitu Wiraswasta sebanyak 49 responden $(47,6 \%)$

\section{Responden Berdasarkan Tinggal Bersama Siapa \\ Tabel 6 Tabel distribusi responden berdasarkan berdasarkan Tinggal}


Bersama Siapa di STIKes William Boot

\begin{tabular}{|c|c|c|c|}
\hline No & $\begin{array}{c}\text { Tinggal } \\
\text { Bersama } \\
\text { Siapa }\end{array}$ & $\begin{array}{c}\text { Jumlah } \\
\text { Responde } \\
\text { n }\end{array}$ & $\begin{array}{c}\text { Presentas } \\
\text { e }(\%)\end{array}$ \\
\hline 1. & Orang tua & 51 & $49,5 \%$ \\
\hline 2. & Kos & 29 & $28,2 \%$ \\
\hline 3. & Asrama & 14 & $13,6 \%$ \\
\hline 4. & $\begin{array}{c}\text { Wali/keluar } \\
\text { ga }\end{array}$ & 9 & $8,7 \%$ \\
\hline & Total & 103 & $100 \%$ \\
\hline
\end{tabular}

Berdasarkan Tabel 6 dapat diketahui bahwa sebagian besar responden tinggal bersama orang tua yaitu sebanyak 51 responden $(49,5 \%)$

\section{Data Khusus}

Data khusus dalam bab ini mengidentifikasi Self-Efficacy Remaja Pecandu Narkoba di Rumah Sehat Orbit Margorejo Indah Utara Surabaya

\section{Distribusi Self - Efficacy Mahasiswa}

Tabel 8 Tabel distribusi Frekuensi SelfEfficacy Mahasiswa di STIKes William Booth

\begin{tabular}{|c|c|c|c|}
\hline No. & Self-Efficacy & Frekuensi & $\begin{array}{c}\text { Presentase } \\
(\%)\end{array}$ \\
\hline 1. & $\begin{array}{c}\text { Self-Efficacy } \\
\text { tinggi }\end{array}$ & 68 & $66 \%$ \\
\hline 2. & $\begin{array}{c}\text { Self-Efficacy } \\
\text { rendah }\end{array}$ & 35 & $34 \%$ \\
\hline & Total & 103 & $100 \%$ \\
\hline \multicolumn{2}{|c|}{}
\end{tabular}

Berdasarkan tabel 5.9 didapatkan bahwa Self - Efficacy mahasiswa Stikes William Booth bahwa sebagian besar responden memiliki Self-Efficacy Tinggi yaitu sebanyak 68 responden $(66 \%)$

\section{PEMBAHASAN}

Berdasarkan data yang hasil yang didapat Sebagian besar mahasiswa memiliki Self-Efficacy yang tinggi yaitu 68 responden atau 66\%. Menurut Bandura (1993) factor-factor yang mempengaruhi Self - Efficacy seseorang adalah insentif eksternal, pengalaman orang lain, dukungan sosial, sifat tugas yang dihadapi, dan pengalaman pribadi. Bila dikaitkan dengan penelitian ini maka pengalaman pribadi dari mahasiswa sesuai dengan pendapat Bandura ini. Bila dilihat dari tabel 2 maka tampak bahwa mahasiswa terbanyak adalah tingkat 2. Hal ini menunjukkan bahwa mereka sudah belajar pada tahun ke 2 di STIKES William Booth sehingga mereka sudah memiliki pengalaman belajar disana, sudah mengenal para dosen sehingga mereka memililiki Self-efficacy yang tinggi. Dengan adanya pengalaman belajar di Stikes ini maka mereka sudah tahu bagaimana caranya dan apa yang harus mereka lakukan ketika mereka menghadapi hambatan atau masalah dalam belajar sekalipun dalam proses belajar daring ini. Menurut Niken (2020) dengan adanya pembelajaran daring maka memberi dampak mahasiswa dalam belajar dapat mengefiensi waktu, menciptakan komunitas belajar, dapat mengakses bahan belajar dengan kecanggihan tehnologi. Hal ini juga dapat digunakan mahasiswa untuk membentuk kelompok bersama teman yang sudah dikenalnya, berdiskusi secara langsung dengan dosen yang sudah dikenalnya melalui tehnologi sehingga mereka memiliki keyakinan atau Selfefficacy yang tinggi dalam proses pembelajaran selama daring ini.

Demikian juga dengan sifat tugas yang mereka hadapi. Menurut Monika Adman (2017) Efikasi diri merupakan keyakinan individu mengenai kempuannya dalam menghadapi sesuatu. Mahasiswa yang belajar di Stikes William Booth sudah mengetahui tujuan mereka kuliah disini untuk menjadi perawat dan Bidan professional. Maka Ketika wabah covid-19 
ini melanda seluruh dunia maka mereka menyadari bahwa mereka adalah caloncalon tenaga kesehatan yang juga memiliki peran penting untuk pencegahan penyebaran Covid-19 ini. Hal ini menyebabkan mahasiswa menyadari tujuan dari pembelajaran jarak jauh sehingga mereka tetap memiliki motivasi dalam belajar dan memiliki Self-efficacy yang tinggi bahwa mereka mampu belajar dan menyelesaikan segala hambatan dalam belajar pada masa pandemic ini dengan baik.

Self-efficacy mahasiswa tinggi pada penelitian ini juga dapat disebabkan karena adanya dukungan social yang mereka dapatkan dari keluarga mereka. Bila dilihat pada table 4 dimana tingkat Pendidikan dari orang tua Sebagian besar adalah lulusan SMA dan pada tabel 6 didapatkan data bahwa Sebagian besar mahasiwa tinggal bersama orang tua. Menurut Notoadmojo (2003) tingkat pendikan menetukan sikap dan perilaku seseorang. Hal ini menunjukkan bahwa orang tua selalu memberi dukungan kepada anaknya dan memotivasi putra putrinya agar tetap belajar dengan baik sekalipun pembejarannya secara daring. Dengan tingkat Pendidikan yang baik ini orang tua dapat menilai kondisi pandemic dengan melihat dari segi positifnya sehingga mereka tetap memberikan semangat kepada anaknya untuk terus berjuang dan belajar untuk mencapai cita cita mereka sehingga hasilnya menunjukkan Selfefficacy mahasiswa tinggi.

Dalam penelitian ini juga ditemukan mahasiswa yang memiliki Self-efficacy yang rendah yaitu sebanyak 35 mahasiswa (34\%). Menurut Niken (2020) ada beberapa dampak pembelajaran daring yaitu; mahasiswa menjadi pasif, kurang kreatif dan produktif,; membingungkan mahasiswa penumpukan informasi/ konsep pada mahasiswa kurang bermanfaat; mahasiswa mengalami stress; serta peningkatan kemampuan literasi Bahasa mahasiswa. Adanya Self-efficacy yang rendah ini dapat dipengaruhi karena adanya hambatan yang dialami akibat dampak dari proses pembelajaran daring seperti mahasiswa menjadi stress bukan hanya karena proses pembalajaran itu sendiri tetapi juga factor yang mempengaruhi proses pembelajaran tersebut. Bila dilihat pada tabel 5 dimana Sebagian besar pekerjaan orang tua adalah wiraswasta. Kita tahu bahwa pandemi ini selain Kesehatan maka yang paling dipengaruhinya adalah ekonomi (Firman, 2020) Dengan pekerjaan orang tua yang wirawasta yang artinya mungkin berdampak besar akibat pandemic Covid19 ini sehingga penghasilan orang tua menurun. Akibatnya orang tua mengalami kesulitan dalam membiayai kuliah dan juga biaya hidup dari putra putrinya. Seperti yang dapat kita lihat pada tabel 6 bahwa mahaasiwa ada yang kos dan juga ada yang tinggal di asrama yang astinya terpisah dari orang tua sehingga membutuhkan biaya untuk biaya hidup sehari-hari. Hal ini yang mempengaruhi mahasiswa sehingga mahasiswa tidak memiliki keyakinan yang kuat bahwa mereka mampu melewati proses belajar daring ini dengan baik karena mereka juga butuh biaya untuk proses belajar daring sehingga masih ditemukan mahasiswa memiliki Self-efficacy yang rendah.

Dampak yang lain yaitu mahasiswa menjadi pasif kurang kreatif dan monoton (Niken, 2020). Bila kita melihat pada tabel 2 dimana usia dari mahasiswa adalah usia yang memiliki semangat yang tinggi sehingga mereka sangat aktif dan kreatif akan tetapi karena pandemic Covid 19 sehingga pembelajaran melalui daring dan mereka tidak bisa lebih kreatif lagi dan harus banyak tinggal di rumah akibatnya mereka memiliki Self-efficacy yang rendah.

\section{SIMPULAN}

Berdasarkan hasil penelitian yang telah dilakukan maka dapat disimpulkan sebagai berikut : Self-efficacy mahassiwa Dalam Belajar selama masa pandemic Covid 19 
Sebagian besar memiliki Self-Efficacy Tinggi.

\section{SARAN}

Dengan adanya penelitian ini diharapkan agar institusi tetap meningkatkan proses pembelajaran yang kreatif dan interaktif agar dapat meningkatkan Self-Efficacy mahasiswa dalam belajar

\section{DAFTAR PUSTAKA}

Bandura,A,1993. Perceived self-efficacy in cognitive development and functioning. Educational Psychologist,28,117-148.

Bandura, A. (2010). Self-efficacy Bandura. The Corsini Encyclopedia of Psychology, 1-3

Firman, (2020) Dampak Covid-19 terhadap pembelajaran di Perguruan Tinggi. BIOMA, Vol.2, No.1, Juni 2020, pp. 14 20 file:///C:/Users/HP/Downloads/743Article\%20Text-2758-1-1020200625.pdf

Hawari, Dadang. 2010. Management Stress Cemas Dan Depresi. Jakarta: FKUI.

Khasanah DRAU, Pramudibyanto H, Widuroyekti B. Pendidikan Dalam Masa Pandemi COVID-19. J Sinestesia [Internet]. 2020;10(1):418

https://sinestesia.pustaka.my.id/journa I/article/view/44

Monika, M., \& Adman, A. (2017). Peran Efikasi Diri Dan Motivasi Belajar Dalam Meningkatkan Hasil Belajar Siswa Sekolah Menengah Kejuruan. Jurnal Pendidikan Manajemen
Perkantoran, 2(2), 109. file:///C:/Users/HP/Downloads/docume $\underline{\text { nt.pdf }}$

Niken Bayu Argaheni (2020) Sistematik Review: Dampak Perkuliahan Daring Saat Pandemi Covid-19 Terhadap Mahasiswa Indonesia PLACENTUM Jurnal Ilmiah Kesehatan dan Aplikasinya, Vol.8 (2) 2020 https://jurnal.uns.ac.id/placentum/artic le/view/43008

Notoatmojdo, Soekidjo. 2003. Pendidikan Dan Perilaku Kesehatan. Rineka Cipta. Jakarta.

Nursalam. (2003). Metodologi Riset Keperawatan. Jakarta: Salemba Medika

Yolandaru Septiana (2020) Survey Efikasi Diri Mahasiswa Prodi Pendidikan Akutansi Pada Masa Pembelajaran Jarak Jauh, Jurnal Ekonomi dan Pendidikan Vol 17 no. 2 https://journal.uny.ac.id/index.php/jep Larticle/view/35008

Yusuf, Syamsu. (2010). Psikologi Perkembangan Anak Dan Remaja. Bandung:PT Remaja Rosdakarya 